Apidologie, 1986, 17 (3), 227-232

\title{
REGULATION OF THE HOARDING EFFICIENCY OF AFRICANIZED AND EUROPEAN HONEY BEES
}

\author{
Thomas E. RINDERER, Anita M. COLLINS, Richard L. HELLMICH II, \\ and Robert G. DANKA
}

with the technical collaboration of Alcedes ESCALONA and Vicki LANCASTER

United States Department of Agriculture, Agricultural Research Service

Honey-Bee Breeding Genetics and Physiology Laboratory

1157 Ben Hur Road, Baton Rouge, LA 70820, U.S.A.

\begin{abstract}
SUMMARY
In laboratory cages, European bees hoarded more sucrose solution, and did so with greater efficiency than Africanized bees. Additional empty comb caused both Africanized and European bees to increase both their hoarding intensities and efficiencies. The proportional increase in hoarding intensity was somewhat less for the Africanized bees but the proportional increase in efficiency was similar for Africanized and European bees.
\end{abstract}

\section{INTRODUCTION}

Empty comb in honey-bee (Apis mellifera) nests strongly influences the nectar harvesting of bees (RINDERER, 1981, 1982 ; RINDERER and BAXTER, 1978, 1979, 1980). These studies showed increased hoarding intensities (rates) in laboratory cages (Free and Williams, 1972 ; KulinceVic and RothenbuhleR, 1973) and increased intensities of foraging activities of bees in field conditions caused by increased amounts of empty comb. In addition to intensity, increased amounts of empty comb also result in increased efficiency both in the field (RINDERER, 1982), and in hoarding cages (RINDERER, 1983).

In comparisons with European bees, Africanized bees (descendants of Apis mellifera scutellata, RUTTNER, 1976) seem similar to European bees that are stimulated by lesser amounts of empty comb. This is true of bees in laboratory hoarding experiments (RINDERER et al., 1982) and of bees in field experiments (RINDERER et al., 1984, 1985). These experiments showed that the intensity of hoarding and foraging activities is less for Africanized bees when stimulated 
by the same amount of empty comb. However, the experiments were not designed to compare the responses to increased comb by Africanized and European bees nor were they designed to compare the hoarding efficiencies of these geographical types ${ }^{(1)}$. This report describes an experiment designed to test these variables.

\section{MATERIALS AND METHODS}

For each of three experimental replicates, combs of emerging adult worker bees were collected from the brood nests of five Africanized and five European colonies. These combs were held in an incubator $\left(35^{\circ} \mathrm{C} ; 50 \% \mathrm{RH}\right)$ until the bees were $0-24 \mathrm{~h}$ old. The bees were then placed into laboratory hoarding cages having either $50 \mathrm{sq} \mathrm{cm}$ or $450 \mathrm{sq} \mathrm{cm}$ of exposed surface area of comb. Bees from each colony were caged separately, by groups of 30 in four of each type of cage. Each cage had 3 identical gravity feeders containing either $20 \%(\mathrm{w} / \mathrm{w})$ sucrose in water solution, $50 \%$ sucrose solution or water only. After being stocked with bees, cages were placed in an incubator $\left(35^{\circ} \mathrm{C} ; 50 \% \mathrm{RH}\right)$ and inspected daily for seven days. The amounts of sucrose solution removed from the feeders were measured as weight changes, and feeders were replenished as needed.

This experimental design, giving bees simultaneous access to different sucrose solutions, permitted estimates of hoarding efficiency. These estimates of reward per unit of work were calculated as total grams of sugar hoarded divided by total grams of solution hoarded, and could range from 0.2 (only $20 \%$ solution was hoarded) to 0.5 (only $50 \%$ solution was hoarded). Portions of efficiency estimates derived from the hoarding of the $20 \%$ solution probably inflate the overall efficiency estimate somewhat, since bees tend to take smaller loads of lower quality food (voN Frisch, 1967). This method assumes equal-sized loads. Thus, any differences in efficiency are likely to be more extreme than those calculated by this method.

Data sets for total grams of solution hoarded, total grams of sucrose hoarded and efficiencies were analyzed by analyses of variance.

\section{RESULTS}

Differential hoarding rates and differential hoarding efficiencies occurred between geographical types $(\mathrm{P}<0.001)$ (Table 1$)$. European bees hoarded more sucrose solution with greater efficiency. Additional empty comb caused both Africanized and European bees to increase both their hoarding intensities and efficiencies $(P<0.001)$. The interaction terms in the analyses suggest that the proportional increase was somewhat less for the Africanized bees' hoarding intensity $(\mathrm{P}<0.16)$ but that the proportional increase in efficiency was similar for the two geographical types $(\mathrm{P}<0.55)$.

(1) The European bees in this study were from North America. Such bees have mixed subspecies representatives in their ancestries. The Africanized bees are descendants of $A$. $m$. scutellata imports and their hybrids with various subspecies representatives previously imported to Brazil. Neither the European nor Africanized bees in this study can correctly be referred to as race, subspecies, stock, or line representatives. We use the term «geographic type " to indicate that the bees we studied showed major characteristics typical of descriptions that have been made of temperately or tropically adapted bees. 


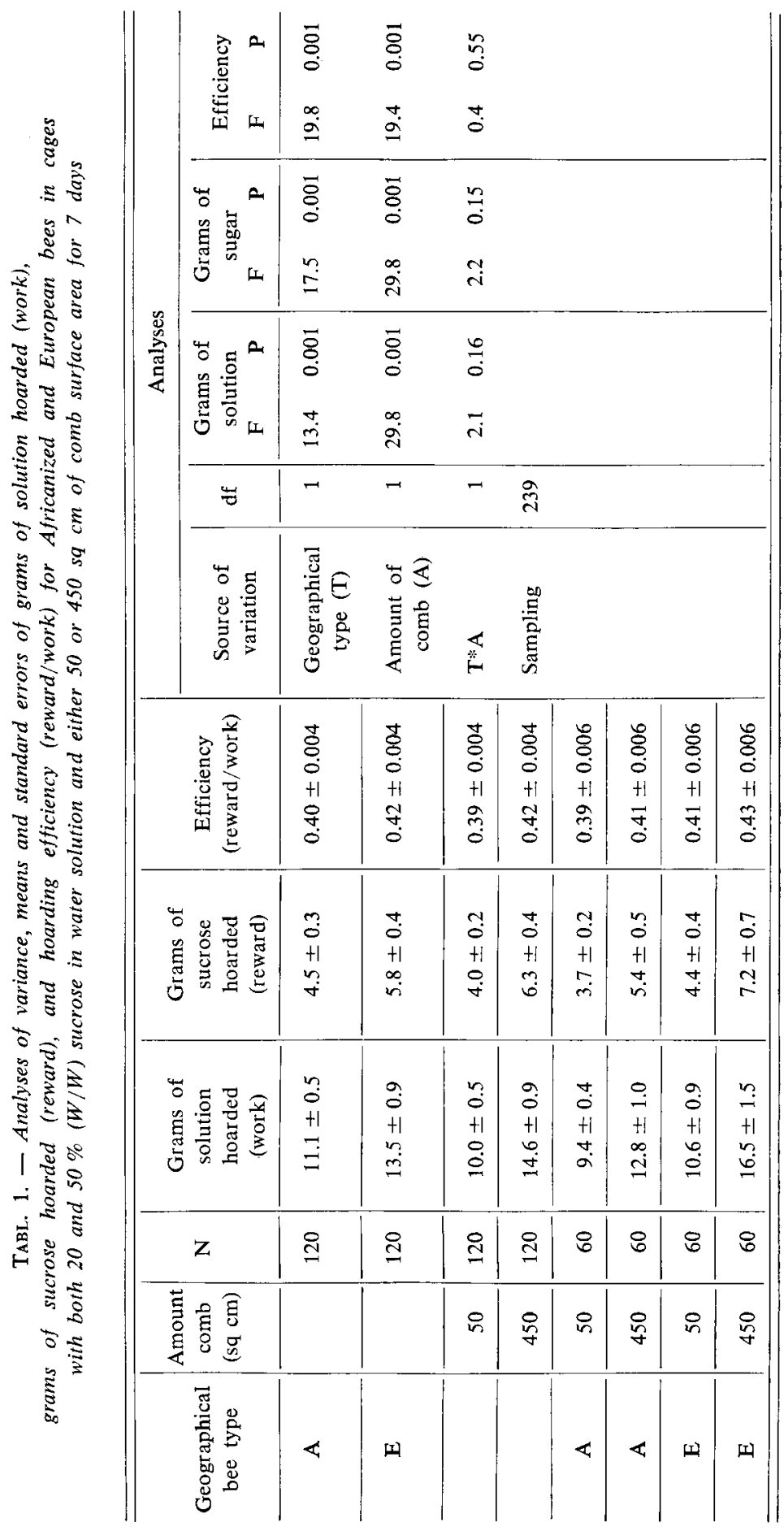




\section{DISCUSSION}

These data confirm previous studies which have shown the superiority of European bees in behavior relating to honey production, (RINDERER et al., 1982, 1984, 1985). Probably these superior honey-production abilities of European bees are tied to the need to survive the predictable nectar dearths of winter and the need to build large populations in spring before the beginning of the nectarflow period in temperate climates. In contrast, Africanized bees are better adapted to the unpredictable, scattered and often marginal nectar-flows commonly found in the tropics. Such resource conditions are best exploited by colonies which are less selective of the quality of the nectar sources they use. In hoarding experiments, calculations of efficiency estimate this selectivity.

The similarities of Africanized bees to European bees when they are less stimulated by empty comb are marked (these data ; loc. cit.; RINDERER, 1982). The regulation of nectar foraging in European-bee nests leads to conditions of small amounts of empty comb and less intense and less selective (or efficient) foraging, especially during the autumn (RINDERER, 1982). These foraging patterns are appropriate to the autumn nectar-flow conditions in temperate areas. Africanized bees are adapted to foraging poorer quality nectar flows and may do well in temperate autumn flows.

Since swarming of Africanized bees is resource related (WInston et al., 1980) this suggests that Africanized bees may show strong autumn swarming rates in North America. If they do, many Africanized queens from these swarms may invade and inhabit European colonies as is often the case in South America (personal observation). Since the bees in such colonies would be primarily European at the onset of winter, the colonies would have good chances to survive even long winters. These conditions would expand the overwintering range of Africanized bees in North America predicted by TAYLOR and SPIVAK (1984), and may in part explain the observation of overwintered Africanized colonies in unexpected portions of southern Argentina (DIETZ et al., 1985).

Received for publication in December 1985.

Accepted for publication in May 1986.

\section{RÉSUME \\ REGULATION DE L'EFFICACITE D'AMASSEMENT CHEZ LES ABEILLES AFRICANISEES ET EUROPEENNES}

On a placé des abeilles provenant de 15 colonies africanisées et de 15 colonies européennes dans des cages possédant une surface de rayon soit de $50 \mathrm{~cm}^{2}$, soit de $450 \mathrm{~cm}^{2}$. Chaque cage était 
pourvue d'un nourrisseur par gravité avec une solution de saccharose à $20 \%$, d'un second nourrisseur avec une solution de saccharose à $50 \%$ et d'un troisième avec uniquement de l'eau.

Les cages ont été observées durant 1 semaine et l'intensité d'amassement a été évaluée d'après le nombre de grammes de solution et le nombre de grammes de saccharose prélevés dans les nourrisseurs. L'efficacité d'amassement a été évaluée d'après le rapport grammes de saccharose/ grammes de solution. L'efficacité s'étend de 0,2 à 0,5 selon que la solution amassée était respectivement à $20 \%$ ou à $50 \%$.

Les abeilles européennes ont amassé plus que les africanisées $(E=13,5 \pm 0,9$ grammes de solution; $A=11,1 \pm 0,5 ; P<0,001)$ et avec une plus grande efficacité $(E=0,42 \pm 0,004$; $A=0,40 \pm 0,004 ; P<0,001$ ) (Tabl. 1). Si l'on ajoutait des rayons vides, les abeilles européennes aussi bien qu'africaines augmentaient leur intensité et leur efficacité d'amassement $(P<0,001)$. L'accroissement de l'intensité d'amassement a été légèrement plus faible chez les abeilles africanisées que chez les européennes $(P<0,16)$, mais l'accroissement de l'efficacité a été semblable $(P<0,55)$.

\title{
ZUSAMMENFASSUNG
}

\author{
REGULIERUNG DER LEISTUNGSFAHIGKEIT AFRIKANISIERTER \\ UND EUROPAISCHER HONIGBIENEN BEIM EINTRAGEN VON SIRUP
}

Arbeiterinnen von 15 Afrikanisierten und 15 europäischen Bienenvölkern wurden in Laborkäfige gebracht, in denen entweder $50 \mathrm{~cm}^{2}$ oder $450 \mathrm{~cm}^{2}$ Wabenfläche dargeboten wurden. Jeder Käfig war mit drei Futtergefäßen versehen, einer mit $20 \%$ wässriger Saccharosellösung (W/W), der zweite mit $50 \%$ Saccharoselösung und ein dritter mit Wasser allein.

Die Käfige wurden eine Woche lang beobachtet, wobei die Eintragsleistung in Gesamtmenge an Lösung und an Saccharose (beides in Gramm), entnommen aus den Futtergefäßen, gemessen wurden. Die Leistungsfähigkeit konnte zwischen 0,2 (nur die $20 \%$ Lösung wurde abgenommen) und 0,5 (nur die $50 \%$ Lösung wurde abgenommen) schwanken.

Europäische Bienen trugen nicht nur mehr ein als Afrikanisierte $(E=13,5 \pm 0,9 \mathrm{~g}$ Lösung; $A=11,1 \pm 0,5 ; P<0,001)$, sie sammelten auch mit größerer Leistungsfähigkeit $(E=0,42 \pm 0,004$; $\mathbf{A}=0,40 \pm 0,004 ; \mathbf{P}<0,001) \quad(T a b, 1)$. Zugabe von leeren Waben steigerte bei Afrikanisierten wie bei europäischen Bienen sowohl die Intensität wie die Leistungsfähigkeit des Eintragens $(\mathbf{P}<0,001$. Die Steigerung der eingetragenen Futtermege (d.h. der Sammelintensität) war bei den Afrikanis:erten Bienen etwas schwächer als bei den europäischen $(P<0,16)$, aber die Zunahmen an Leistungsfähigkeit waren ähnlich $(P<0,55)$.

\section{REFERENCES}

Dietz A., Krell R., Eischen F., 1985. - Preliminary investigation on the distribution of Africanized honeybees in Argentina. Apidologie, 16, 99-108.

Free J.B., Williams I.H., 1972. - Hoarding by honeybees (Apis mellifera L.). Anim. Behav., 20, 327-334.

FriscH K. von, 1967. - The dance language and orientation of bees. - Belknap Press of Harvard Univ. Press, Cambridge, $566 \mathrm{pp}$.

Kulincevic J.M., RothenbuhleR W.C., 1973. - Laboratory and field measurements of hoarding behaviour in the honeybee (Apis mellifera). J. Apic. Res., 12, 179-182. 
Rinderer T.E., 1981. - Volatiles from empty comb increase hoarding by the honeybee. Anim. Behav., 29, 1275-1276.

Rinderer T.E., 1982. - Regulated nectar-harvesting of the honeybee. J. Apic. Res., 21, 74-87.

RiNDERER T.E., 1983. - Regulation of honey bee hoarding efficiency. Apidologie, 14, 87-89.

RINDERER T.E., BAXTER J.R., 1978. - Effect of empty comb on hoarding behavior and honey production of the honeybee. J. Econ. Entomol., 71, 757-759.

RINDERER T.E., BAXTER J.R., 1978. - Honey bee hoarding behaviour : Effects of previous stimulation by empty comb. Anim. Behav., 27, 426-428.

Rinderer T.E., BaXter J.R., 1980. - Hoarding behavior of the honeybee : Effects of empty comb, comb color, and genotype. Environ. Entomol., 9, 104-105.

Rinderer T.E., Bolten A.B., Harbo J.R., Collins A.M., 1982. - Hoarding behavior : European and Africanized honey bees. J. Econ. Entomol., 75, 714-715.

Rinderer T.E., Bolten A.B., Collins A.M., Harbo J.R., 1984. - Nectar-foraging characteristics of Africanized and European honey bees in the neotropics. J. Apic. Res., 23, $70-79$.

Rinderer T.E., Collins A.M., Tucker K.W., 1985. - Honey production and underlying nectar harvesting activities of Africanized and European honeybees. J. Apic. Res., 24, 161-167.

Rutrner F., 1976. - African races of honeybees. Proc. 25 Int. Beekeep. Congr. Grenoble, 325-344.

TAYLOR O.R., SPIVAK M., 1984. - Climatic limits of tropical African honeybees in the Americas. Bee World, 65, 38-47.

Winston M.L., TAYLoR O.R., Otis G.W., 1980. - Swarming, colony growth patterns and bee management. Am. Bee J., 120, 826-830. 